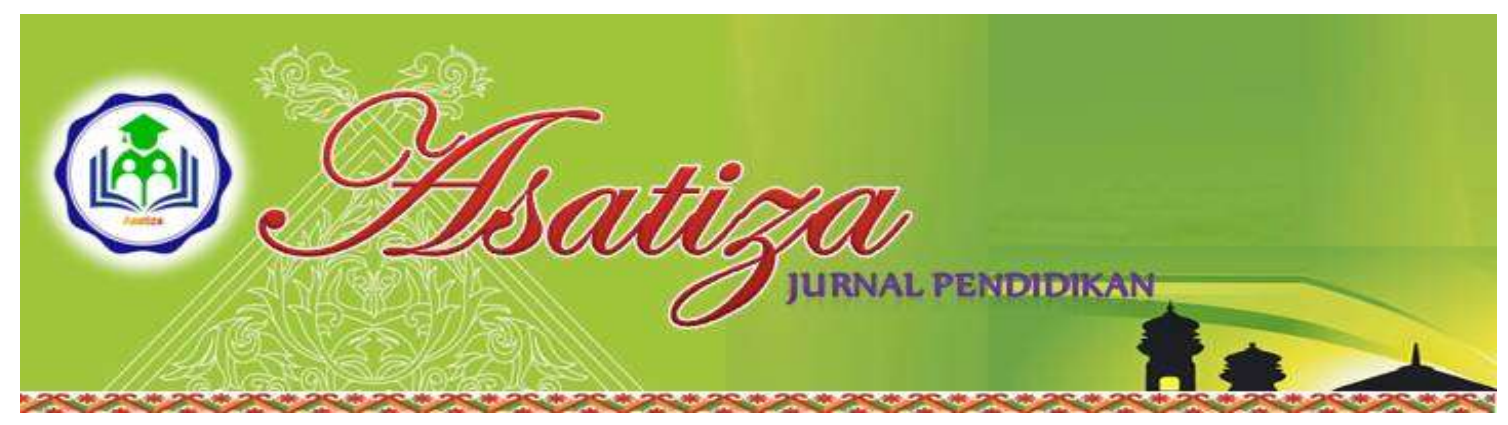

\title{
PERPADUAN SAINTIFIK APROACH DENGAN DISCOVERY LEARNING DALAM MEWUJUDKAN PEMBELAJARAN EFEKTIF Saidan Lubis ${ }^{1}$
}

${ }^{1}$ Balai Diklat Keagamaan Padang, Sumbar, Indonesia

\begin{abstract}
Abstrak
Karya tulis dengan judul "Perpaduan Saintifik Aproach dengan Discovery Learning dalam Mewujudkan Pembelajaran Efektif (Kajian DTS Guru Mata Pelajaran Ushul Fikih Di BDK Padang), sebuah penelitian lapangan menggunakan pendekatan kualitatif deskriptif dengan metode survey dan wawancara. Penelitian ini dilatar belakangi oleh kondisi pembelajaran dalam Diklat Teknis Susbtantif Guru Mata Pelajaran Ushul Fikih MAK yang tidak efektif karena ditengarai pembelajaran tidak menggunakan pendekatan yang merefleksikan alur pikir yang ilmiah dan model pembelajaran yang adaptif. Sementara mata pelajaran Ushul Fiqh berisikan materi sebagai sebuah epistemologi dengan alur pikir hukum yang ilmiah dan metode penetapan hukum dalam syariat Islam. Rumusan permasalahan dalam kajian ini adalah Bagaimana Perpaduan antara Saintifik Approach dengan Model Discovery Learning Mewujudkan Pembelajaran yang Efektif dalam kegiatan Diklat Guru Mata Pelajaran Ushul Fikih MAK di Balai Diklat Keagamaan Padang Tahun 2019?

Hasil penelitian menunjukkan bahwa, perpaduan antara pendekatan saintifik dengan penerapan model discovery learning dalam kegiatan diklat guru mata pelajaran Ushul Fikih MAK bisa menjadikan pembelajaran semakin efektif, karena melalui pendekatan saintifik dan model discovery learning mengadopsi langkah-langkah saintis dalam membangun pengetahuan dan mendorong peserta diklat untuk memiliki kecakapan berpikir kreatif untuk mengidentifikasi atau menemukan masalah, merumuskan, mengajukan atau merumuskan hipotesis, mengumpulkan data dengan berbagai teknik, menganalisis data, menarik kesimpulan dan mengomunikasikan konsep, hukum atau prinsip yang ditemukan, hal ini sesuai dengan alur pikir yang terkandung dalam materi Ushul Fikih itu sendiri." Perpaduan antara pendekatan saintifik dengan model pembelajaran discovery learning sangat berarti dalam mendorong dan melatih peserta diklat melalukan penyelidikan (al-kasyf), menemukan sendiri sesuatu yang dipelajari dan pada gilirannya menghasilkan pengetahuan yang benarbenar bermakna.
\end{abstract}

Kata Kunci: Saintifik Approach, Discovery Learning 


$$
\begin{aligned}
& \text { الكتابة العلمية بعنوان "اندماج المنهج العلمي مع التعلم بالاكتشاف في تحقيق التعلم الفعال (دراسة } \\
& \text { فلسفية لمدرسى أصول الفقه في للمدرسة الثانوية الدينية) وهو بحث ميداني يستخدم المنهج الوصفي النوعي }
\end{aligned}
$$

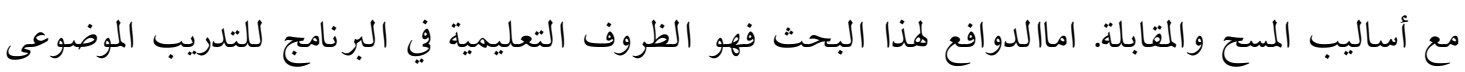

$$
\begin{aligned}
& \text { الفني لمدرسى أصول الفقه، وهو أمر غير فعال لأنه يشتبه في أن التعلم مرتكز بين يدي المدرسين لا يستخدم } \\
& \text { منهجًا موصلا بتدفق التفكير العلمي ونماذج التعلم الاكتشافى. في حين أن مواضيع أصول الفقه تحتوي على مادة } \\
& \text { باعتبارها نظرية المعرفة مع عقلية قانونية علمية وطرق تحديد القانون في الشريعة الإسلامية. أوضحت النتائج أن } \\
& \text { الجمع بين المدخلات العلمية وتطبيق طريقة تعلم الاكتشاف في الأنشطة التدريبية لمواد أصول الفقه يمكن أن } \\
& \text { يجعل التعلم أكثر نافةفاعلية مباشرة، لأنه من جانب منهج علمي و تعلم اكتشافى اعتمد على الخطوات العلمية } \\
& \text { في بناء المعرفة وتشجيع المشاركين في التدريب لكى يكون لديهم مهارات التفكير الإبداعي لتحديد أو العثور } \\
& \text { على المشاكل، وصياغة أو اقتراح أو صياغة الفرضيات ، وجمع البيانات مع مختلف الاساليب ، وتحليل البيانات، } \\
& \text { واستخلاص النتائج وإيصال المفاهيم أو القوانين أو المبادئ الموجودة، وهذا يتوافق مع تدفق الفكر الوارد في مادة } \\
& \text { أصول الفقه فإلنهاية ان الجمع بين النهج العلمي والتعلم بالاكتشاف ذو مغزى كبير في تشجيع وتدريب } \\
& \text { المشاركين على إجراء تحقيق (الكشف) ففى دوره إنتاج المعرفة التي تتم لها معنى حقيقي. } \\
& \text { لب البحث: المدخل العلمى الاكتشاف التعلمى }
\end{aligned}
$$

\section{A. PENDAHULUAN}

\section{Latar belakang}

Istilah pembelajaran menunjukkan interaksi yang aktif secara timbal balik antara pendidik dengan peserta didik atau antara widyaiswara dengan peserta diklat. Pembelajaran yang ideal itu merupakan komunikasi dua arah yang melibatkan peserta didik dalam kegiatan dan proses pembelajaran. Agar pembelajaran itu dapat berjalan secara efektif dan efisien, maka kegiatan belajar mengajar itu haruslah mengarah pada kemandirian peserta didik. Menurut teori konstruktivisme seperti yang dirumuskan I Wayan Sadia (2014: 5) belajar itu merupakan proses pengkonstruksian. Oleh karena itu, peserta didik harus dapat menemukan dan mentransformasikan informasi yang kompleks, mengecek informasi baru dengan aturan-aturan lama dan merevisinya jika aturan-atura itu tidak sesuai lagi. Ini menunjukan bahwa, pembelajaran itu harus sesuai dengan tuntutan kondisi dan karakteristik peserta didik.

Peserta didik/peserta diklat merupakan objek dan sekaligus subjek pembelajaran yang kondisinya sangat dinamis dan penuh "misteri" memerlukan kearifan dan kepiawaian dalam menghadapinya dan membutuh-kan trik untuk menarik minat mereka agar aktif dalam pembelajaran. Hal ini mengisyarat kan bahwa, pendidik / widyaiswara haruslah memahami dan mengerti dalam menggunakan pendekatan, metode, dan model pembelajaran yang dapat mengaktifkan mereka.

Keaktifan peserta didik dalam pembelajaran merupakan salah satu 
karakteristik dan tuntutan dari kurikulum 2013 dan inilah yang membedakannya dengan kurikulum-kurikulum sebelumnya. Pembelajaran versi kurikulum 2013 itu adalah pemberian motivasi untuk mencari "tahu", bukan memberi tahu peserta didik/siswa. Di samping itu, pendidik dituntut melaksanakan kegiatan pembelajaran menggunakan pendekatan saintifik yaitu suatu alur memperoleh pengetahuan menurut kajian filsafat.

Penerapan pendekatan pembelajar an yang efektif dan sesuai dengan materi dan tujuan pembelajaran semisal saintifik akan memberikan motivasi belajar bagi peserta didik/peserta diklat, dan akan menumbuhkan kegairahan dalam mengikuti kegiatan pembelajaran. Namun sebaliknya, penerapan sebuah pendekatan yang tidak relevan dan tidak sesuai dengan tujuan tentu akan menjadi kendala dan menjauhkan pembelajaran dari tujuan yang diharapkan.

Agar tercapai tujuan yang ditargetkan, ada tiga istilah menurut bahasa Arab yang sering digunakan dalam pembelajaran yaitu: (1) almadkhal dengan arti pendekatan, (2) aluslub dengan arti teknik dalam pembelajaran yaitu suatu kiat atau gaya mengajar yang digunakan, dan (3) althariqah dengan arti metode yaitu suatu cara mentransfer pengetahuan kepada orang lain. Al-Thariqah atau metode itu lebih urgen dari materi.

(al-tharĭqah ahm min almawõd)

$$
\text { الطريقة أهم من المو اد اد }
$$

Paradigma baru dalam pendidikan memandang pembelajaran tidak lagi hanya bertumpu pada pendidik/guru yang mengajar dalam bentuk komunikasi satu arah, sementara di pihak lain peserta didik/siswa hanya duduk manis membisu dan menjadi pasif, tidak berani bicara apalagi memberikan pendapat. Pembelajaran terkonsentrasi pada kegiatan pendidik/guru tanpa melibatkan peserta didik/siswa.Begitu juga halnya dalam kegiatan kediklatan, peserta diklat tidak saatnya lagi hanya menerima dari narasumber/widyaiswara, akan tetapi harus berperan aktif dalam pembelajaran. Dengan kata lain, kegiatan pembelajaran harus melibat kan peserta didik/peserta diklat, maka salah satu model yang relevan dengan pendekatan saintifik tersebut adalah discovery learning.

Discovery learning merupakan sebuah model pembelajaran diperkenal kan kurikukulum 2013 yang sesuai dengan pola pendekatan saintifik yaitu suatu kiat yang dilaksanakan oleh guru dalam pembelajaran dengan penerapan metode lima M (mengamati, menanya, menalar, mengasosiasi, dan mengkomunikasikan). Pendekatan ini merupakan metode ilmiah untuk memperoleh pengetahuan yang dimulai dari mengamati melalui pandangan mata, mendengar atau membaca dan observasi. Konsep dasar pendekatan ilmiah ini seirama dengan firman Allah:

و الله أخرجكم من بطون أمهاتكم لا تعلمون شيئا

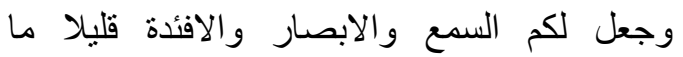
تشكرون (النحل: 78).

Artinya: Allah mengeluarkan kamu dari perut ibu kamu masing-masing tanpa mengetahui sesuatupun, lalu Ia menjadikan bagi kamu pendengaran, penglihatan, dan hati, supaya kamu dapat bersyukur (al-Nahl:78) 
Berdasarkan latar belakang di atas, maka pendekatan saintifik yang dipadukan dengan penerapan model discovery learning dalam kegiatan pembelajaran terutama dalam Diklat Teknis Substantif guru mata pelajaran Ushul Fiqh MA sangat menarik untuk diteliti. Untuk mendapatkan data yang diperlukan, penulis mengadakan penelitian di Balai Diklat Keagamaan Padang dengan rumusan masalahnya "Bagaimana Perpaduan antara Saintifik Approach dengan Model Discovery Learning Mewujudkan Pembelajaran yang Efektif dalam kegiatan Diklat Guru Mata Pelajaran Ushul Fikih MAK di Balai Diklat Keagamaan Padang Tahun 2019?".

\section{Identifikasi Masalah}

Beranjak dari pemikiran yang merupakan latar belakang pemilihan judul karya tulis ini, ada beberapa permasalahan yang diapungkan dalam penelitian ini yaitu :

a. Peserta diklat teknis susbtantif guru mata pelajaran Ushul Fikih MAK tidak seluruhnya berlatar belakang sarjana Fakultas Tarbiyah Pendidikan Agama Islam (PAI) yang memahami pendekatan dan metodologi pembelajaran ;

b. Materi diklat yang ditetapkan dalam diklat guru mata pelajaran Ushul Fikih MAK kurang/tidak relevan dengan tuntutan peserta diklat;

c. Pembelajaran tidak efektif karena kegiatan belajar mengajar terkonsentrasi kepada narasumber/ widyaiswara yang mengajar tanpa penerapan pendekatan dan model pembelajaran yang adaptif ; d. Narasumber kurang menguasai materi Diklat sehingga terkesan kegiatan tidak memberi arti bagi peserta Diklat;

e. Sarana dan prasarana serta fasilitas pendukung yang dimilki oleh Balai Diklat Keagamaan (BDK) Padang kurang memadai dan kurang mendukung kegiatan pembelajaran.

Untuk mengidentifikasi masalahmasalah seperti yang digambarkan di atas, perlu adanya pisau analisis untuk menentukan masalah yang prioritas dan krusial yaitu menggunakan metode USG (Urgency, Seriousness, Growth). Penggunaan metode ini menurut Purwastuti (2016:38) melihat seberapa mendesak masalah yang harus dibahas dikaitkan dengan pentingnya masalah itu dibandingkan dengan masalah lain serta kemungkinan berkembangnya masalah lain bilamana tidak ditangani. Penerapan metode ini dapat dilihat pada tabel berikut:

Tabel 1 :

Penerapan USG

\begin{tabular}{|c|l|l|l|l|l|}
\hline No & Deskripsi Masalah & U & S & G & $\begin{array}{c}\text { To } \\
\text { Tal }\end{array}$ \\
\hline & $\begin{array}{l}\text { Peserta Diklat Teknis } \\
\text { Substantif guru mata } \\
\text { pelajaran Ushul Fikih } \\
\text { MAK tidak seluruh } \\
\text { nya berlatar belakang }\end{array}$ & & & & \\
\hline & $\begin{array}{l}\text { Fakultas Tarbiyah } \\
\text { Pendidikan Agama } \\
\text { Islam (PAI) yang } \\
\text { memahami meto- } \\
\text { dologi pembelajaran; }\end{array}$ & 4 & 4 & 12 \\
\hline 2 & $\begin{array}{l}\text { Materi diklat yang } \\
\text { ditetapkan dalam dik- } \\
\text { lat kurang / tidak } \\
\text { relevan dengan tun- } \\
\text { tutan peserta diklat }\end{array}$ & 4 & 5 & 4 & 13 \\
\hline 3 & $\begin{array}{l}\text { Pembelajaran tidak } \\
\text { efektif karena kegiat } \\
\text { an belajar mengajar } \\
\text { terkonsentrasi kepada } \\
\text { widyaiswara yang } \\
\text { mengajar tanpa }\end{array}$ & 5 & 5 & 4 & 14 \\
\hline
\end{tabular}




\begin{tabular}{|c|c|c|c|c|c|}
\hline & $\begin{array}{lr}\text { penerapan pendekat- } \\
\text { an dan } & \text { model } \\
\text { pembelajaran } & \text { yang } \\
\text { adaptif } & \end{array}$ & & & & \\
\hline 4 & $\begin{array}{ll}\text { Narasumber/ } & \text { widya- } \\
\text { iswara } & \text { kurang } \\
\text { menguasai } & \text { materi } \\
\text { diklat } & \\
\end{array}$ & 4 & 5 & 4 & 13 \\
\hline 5 & $\begin{array}{l}\text { Sarana dan prasarana } \\
\text { serta fasilitas pendu- } \\
\text { kung yang dimilki } \\
\text { oleh Balai Diklat } \\
\text { Keagamaan (BDK) } \\
\text { Padang kurang mema } \\
\text { dai dan kurang } \\
\text { mendukung kegiatan } \\
\text { pembelajaran dalam } \\
\text { kegiatan diklat }\end{array}$ & 5 & 4 & 3 & 12 \\
\hline
\end{tabular}

Berdasarkan skala likert dari ketiga istilah itu (USG); 1-5 (5=sangat besar, 4=besar, 3=sedang, 2=kecil, 1=sangat kecil).

Dari berbagai permasalahan seperti tertera di atas, maka masalah yang menjadi prioritas utama dan paling menonjol adalah No.3 yaitu masalah proses pembelajaran yang tidak efektif karena kegiatan belajar mengajar terkonsentrasi kepada widyaiswara yang mengajar tanpa penerapan pendekatan dan model pembelajaran yang adaptif. Padahal materi Ushul Fikih itu menggambarkan alur pikir ilmiah dan membutuhkan pendekatan yang ilmiah pula.

\section{Rumusan Masalah}

Agar pembahasan tidak melebar ke sana ke mari dan terhindar dari hal-hal yang tidak relevan dan dapat memudahkan peneliti dalam pembahasan, maka peneliti perlu merumuskan maslah yang diteliti yaitu : Bagaimana Perpaduan antara Saintifik Approach dengan Model Discovery Learning Mewujudkan Pembelajaran yang Efektif dalam Pembelajaran Diklat
Guru Mata Pelajaran Ushul Fikih MAK di Balai Diklat Keagamaan Padang Tahun 2019 ?".

\section{Tujuan Penulisan}

Tujuan yang menjadi obsesi dari penelitian dengan judul seperti digambarkan di atas, secara garis besarnya adalah untuk:

a. Mengetahui gambaran dari saintifik approach dan penerapan model discoveri learning dalam pembelajaran Ushul Fikih MAK;

b. Mengetahui kondisi dan suasana pembelajaran melalui perpaduan antara pendekatan saintifik dan penerapan model discoveyi learning dalam Diklat Guru Mata Pelajaran Ushul Fikih;

c. Mengetahui keefektifan pembelajaran dengan penerapan perpaduan saintifik approach dengan model discovery dalam diklat guru mata pelajaran Ushul Fikih MAK di Balai Diklat Keagamaan Padang tahun 2019.

\section{Kerangka Teori}

a. Pendekatan Saintifik (Scientific Approach) dalam Pembelajaran

Saintifik approach berasal dari kata scientific approach merupakan pendekatan pembelajaran yang mengadopsi langkah-langkah saintis dalam membangun pengetahuan melalui metode ilmiah. Penerapan model saintifik ini mendorong peserta didik/peserta diklat untuk memiliki kecakapan berpikir sains, dan kemampuan berpikir kreatif. Kelebihan pendekatan ini adalah, para peserta didik/peserta diklat tidak saja memiliki pengetahuan, keterampilan, dan sikap, akan tetapi yang lebih penting lagi 
adalah bagaimana cara memperoleh pengetahuan, keterampilan, dan sikap itu sendiri sebagai sebuah epistemologi.

Pendekatan saintifik merupakan sebuah pola pembelajaran yang menggunakan kaidah-kaidah keilmuan yang memuat serangkaian aktivitas pengumpulan data melalui observasi, menanya, eksperimen, mengolah informasi atau data, kemudian mengomunikasikan/menyampaikan hasilnya kepada orang, dalam kurikulum 2013 dikenal dengan istilah $5 \mathrm{M}$ (Kemendikbud, 2014).

Pendekatan saintifik dalam pembelajaran bertujuan antara lain untuk meningkatkan kemampuan berpikir peserta didik, membentuk kemampuan dalam menyelesaikan masalah secara sistematik, menciptakan kondisi pembelajaran supaya peserta didik merasa bahwa belajar merupakan suatu kebutuhan, melatih peserta didik dalam mengemukakan ide-ide, meningkatkan hasil belajar peserta didik, dan mengembangkan karakter peserta didik.

Proses pembelajaran dengan menggunakan pendekatan saintifik diarahkan agar peserta didik mampu merumuskan masalah (dengan banyak menanya), bukan hanya menyelesaikan masalah dengan cara memberikan jawaban semata. Proses pembelajaran diarahkan untuk melatih berpikir analitis (peserta didik diajarkan bagaimana mengambil keputusan) bukan berpikir mekanistis (rutin dengan hanya mendengarkan dan menghafal semata (Majid, 2014).

Pembelajaran dengan pendekatan saintifik berarti proses pembelajaran yang dirancang sedemikian rupa agar peserta didik/peserta diklat secara aktif mengonstruk konsep, hukum atau prinsip melalui tahapan-tahapan mengamati (untuk mengidentifikasi atau menemukan masalah), merumus kan, mengajukan atau merumuskan hipotesis, mengumpulkan data dengan berbagai teknik, menganalisis data, menarik kesimpulan dan meng- komunikasikan konsep, hukum atau prinsip yang "ditemukan" itu. Ini sangat identik dengan pola penetapan suatu hukum yang menjadi hakikat dari kajian Ushul Fikih.

\section{b. Model Discovery Learning}

Discovery Learning dalam bahasa Arab dikenal dengan istilah al-kasuf merupakan model pembelajaran yang mengarah pada upaya mencari dan menemukan memakai prinsip melibat kan peserta didik/peserta diklat dalam kegiatan pembelajaran. Melalui model ini, materi ajar atau bahan ajar disampaikan secara tidak utuh dan tidak dalam bentuk final, peserta didik/peserta diklat didorong dan dimotivasi untuk mencari dan menemukan serta mengidentifikasi dan mengorganisasi kan atau membentuk (konstruktif) apa yang mereka temui dan apa yang mereka pahami.

Penggunaan model discovery learning dalam diklat guru mata pelajaran Ushul Fikih semakin efektif dan peserta didik/peserta diklat memiliki pengalaman dan wawasan karena mereka melakukan sesuatu melalui penyelidikan yang memungkin kan mereka dapat menemukan konsep atau prinsip-prinsip Ushul Fikih bagi diri mereka sendiri. Perpaduan antara pendekatan saintifik dengan model 
pembelajaran discovery learning sangat berarti dalam mendorong dan melatih peserta didik/peserta diklat melalukan penyelidikan (al-kasyf) dan menemu kan sendiri sesuatu yang dipelajari dan menghasilkan pengetahuan yang benarbenar bermakna.

Discovery learning adalah sebuah model pembelajaran aktif yang melibatkan peserta didik dalam kegiatan pembelajaran. Model pembelajaran ini disebut juga dengan pembelajaran menemukan. Menurut Jamil Suprihatiningrum $(2013 ; 241)$ discovery learning itu merupakan suatu komponen penting dalam pendekatan konstruktif yang telah memilki sejarah panjang dalam dunia pendidikan. Inti dari model ini adalah untuk memberi rasa senang kepada peserta dalam menemukan sesuatu oleh mereka sendiri.

Model pembelajaran discovery learning adalah sebuah pola pembelajar an yang secara langsung melibatkan peserta didik/peserta diklat dalam proses pembelajaran. Dalam hal ini pengajar /isntruktur/widayiswara beperan sebagai fasilitor yang mengarahkan kegiatan pembelajaran menuju tercapainya tujuan yang ditetapkan. Dengan melibatkan para peserta didik/peserta diklat dalam pembelajaran, berarti pembelajaran tidak lagi terfokus pada instruktur/widya iswara yang mengajar, akan tetapi sama berperan dan terlibat dalam menemukan sesuatu.

Pandangan di atas seirama dengan pendapat Abuddin Nata (2009:195) yang mengatakan bahwa, metode penemuan adalah cara penyajian pelajaran yang banyak melibatkan peserta didik dalam proses mental dalam rangka menemukan sesuatu yang diperlukan untuk mengembangkan, menyempurnakan dan perbaikan konsep. Prinsip utama dalam penerapan model discovery learning adalah, materi ataupun bahan pelajaran tidak disampaikan secara utuh ataupun dalam bentuk final. Narasumber /widyaiswara mendorong para peserta didik/peserta diklat mengidentifikasi maeri yang diinginkan dengan mencari informasi sendiri, lalu mengorganisasi kan atau mengkonstruksi apa yang mereka pahami itu.

Karakteristik dari model discovery learning itu memberikan dorongan kepada peserta didik/peserta diklat untuk belajar aktif yaitu melalui keterlibatan mereka secara langsung. Dengan demikian, para peserta didik/peserta diklat dapat berhubungan langsung dan melakukan percobaan yang memungkin kan mereka dapat menemukan yang mereka cari.

Secara garis besar, keunikan model discovery learning dibandingkan dengan model-model lainnya menurut Hosnan (2014:17) adalah: instruktur/widyaiswara berperan sebagai pembimbing; b) peserta didik/peserta diklat akan terlibat langsung dalam pembelajaran secara aktif; c) materi atau bahan ajar yang disajikan berbentuk informasi yang tidak utuh dan tidak lengkap, peserta didik/peserta diklat melakukan kegiatan mencari, menghimpun, menganalisis, mengkonstruksi, dan menyimpulkan.

c. Perpaduan Saintifik Approach dan Model Discovery Learning dalam Pembelajaran Ushul Fiqih

Pembelajaran dengan pola perpaduan antara pendekatan saintifik dengan 
model discovery learning (penemuan) merupakan sebuah model mengajar yang mengatur pembelajaran sedemikian rupa sehingga peserta didik/peserta diklat memperoleh pengetahuan melalui upaya ekpolarasi dan penemuan sendiri. Dalam kegaiatannya, pola pembelajaran ini mengisyaratkan untuk bisa mencari materi ajar dari berbagai sumber. Kegiatan pembelajaran didesain sedemikian rupa agar para peserta didik/peserta diklat bisa menemukan konsep-konsep dan prinsip-prinsip dasar melalui proses mentalnya.

Perpaduan pendekatan saintifik dengan model discovery learning mendorong peserta didik/peserta diklat untuk lebih aktif dalam pembelajaran. Peran pendidik/ widyaiswara adalah sebagai pengarah/pembimbing dan juga sebagai fasilitator. Kondisi seperti ini akan merubah paradigm yang selama ini pembelajaran berpusat pada pendidik/ widyaiswara menjadi pembelajaran berpusat pada peserta didik/peserta diklat.

Penerapan pendekatan saintifik yang dipadu dengan model discovery learning dalam pembelajaran semisal mata pelajaran Ushul Fikih memungkinkan para peserta didik/ peserta diklat dapat menemukan konsep-konsep dan materi ajar secara utuh, dan pembelajaran akan berjalan dengan baik dan kreatif sebab mereka dapat kesempatan untuk mencari dan menemukan konsep, teori dan lainlain sesuai dengan kebutuhan mereka yang dimulai dari pengamatan,menanya, menalar, dan diakhiri dengan mengomunikasikan. Di sinilah letaknya keunggulan model ini, ia merupakan model pembelajaran yang melibatkan peserta didik/peserta diklat berperan aktif dalam pembelajaran. Oleh karena itu menurut Tim Pengembangan MKDP (2011:209), keunggulan model ini karena adanya suasana demokratis dalam pembelajaran.

Model pembelajaran memadukan saintifik dan discovery learning hakikatnya merupakan rangkaian kegiatan pembelajaran yang melibatkan secara maksimal seluruh kemampuan para peserta didik/peserta diklat untuk mencari dan menyelidiki secara sistematis untuk dapat menemukan dan merumuskan sendiri penemuamannya. Dengan demikian, di dalam pembelajar an, para peserta didik/peserta diklat mencari dan menemukan sendiri. Maka pendidik/widyaiswara tidak menyaji kan materi secara utuh dan dalam bentuk final, sehingga peserta didik/peserta diklat diberi peluang untuk mencari dan menemukan sendiri materi yang belum sempurna itu.

Langkah-langkah penerapan saintifik dipadukan dengan model pembelajaran discovery learning adalah sebagai berikut:

1) Mengidentifikasi kebutuhan peserta didik;

2) Menyeleksi pendahuluan meliputi fakta, konsep, prinsip, dan generalisasi pengetahuan;

3) Menyeleksi bahan ajar;

4) Mempersiapkan kelas dan alat-alat yang diperlukan;

5) Mengecek pemahaman peserta didik terhadap masalah yang akan dipelajari;

6) Memberi kesempatan kepada peserta didik untuk melakukan penemuan; 
7) Memberi bantuan kepada peserta didik dalam mencari informasi yang dibutuhkan;

8) Membimbing peserta didik dalam menganalisis dan identifikasi masalah;

9) Memotivasi peserta didik untuk terjadinya interaksi antar sesama peserta didik;

10) Membimbing peserta didik dalam merumuskan dan menjenaralisasi hasil temuan.

Prosedur pembelajaran mengguna kan discovery learning seirama dengan sistematika penerapan saintifik. Prosedur tersebut menurut E. Mulyasa (2014:144), dapat dirangkum sebagai berikut:

1) Stimulus. Pada kegiatan ini pendidik memberikan stimulant berupa bacaan, gambar, dan cerita sesuai dengan materi pembelajaran yang akan dibahas, sehingga peserta didik mendapat pengalaman belajar mealui kegiatan membaca, mengamati situasi atau melihat gambar.

2) Identifikasi masalah (prolem statement). Pada tahap ini peserta didik diharuskan menemukan permasalahan, mereka diberikan pengalaman untuk menanya, mengamati, mencari informmasi, dan mencoba merumuskan masalah.

3) Pengumpulan data. Pada tahap ini, peserta didik diberikan pengalaman mencari dan mengumpulkan data/ informasi yang dapat dugunakan untuk pemecahan masalah yang dihadapi.

4) Pengolahan data (data processing).

5) Verifikasi (verification). Tahap ini mengarahkan peserta didik untuk mengecek kebenaran dan keabsahan hasil pengolahan data melalui berbagai kegitan sehingga menjadi suatu kesimpulan.

6) Generalisasi (generalization). Pada kegiatan ini, peserta didik digiring untuk menjenaralisasikan hasil simpulannya.

\section{B. METODOLOGI}

\section{Bentuk dan Jenis Penelitian}

Penelitian ini berbentuk field research dalam bahasa Arab dikenal dengan istilah al-bahts al-maidanyi menggunakan metode deskriptif kualitatif. Penggunaan metode ini berfungsi untuk melihat, meninjau, mengetahui dan memaparkan serta mengungkapkan sesuatu menurut apa adanya (Raichul Amar, 2007 : 52). Penelitian dengan judul seperti digambar kan di atas merupakan penelitian deskriptif kualitatif. Metode penelitian kualitatif sering disebut dengan metode penelitian naturalistik, hal itu menurut Sugiyono (2011: 14) karena dilakukan dalam kondisi yang alamiah, data yang terkumpulpun kelak akan dianalisis secara kualitatif pula.

Sementara menurut Luthfi (2005: 57), penelitian dengan metode kualitatif merupakan penelitian yang menghasil kan data deskriptif berupa kata-kata tertulis dan prilaku yang dapat diamati. Bentuk penelitian kualitatif ini sengaja dipilih kerena menurut penulis/peneliti hanya bertumpu pada pengumpulan data melalui observasi, wawancara, dan metode lainnya yang dapat menghasil kan data secara deskriptif pula.

Dengan redaksi yang berbeda, Arief Furchan (2005:15) menjelaskan hakikat 
penelitian kualitatif itu adalah prosedur penelitian yang menghasil kan data deskriptif. Penelitian yang mendeskripsi kan suatu gejala, fakta, peristiwa atau kejadian yang sedang atau yang sudah terjadi, yaitu tentang keefektifan pembelajaran mengguna kan perpaduan pendekatan saintifik dengan model discovery learning dalam diklat guru mata pelajaran Ushul Fikih MAK di Balai Diklat Keagamaan Padang tahun 2019.

\section{Pendekatan Penelitian}

Mengingat peneilitian ini bersifat deskriptif seperti yang digambarkan sebelumnya, maka dirasa perlu adanya pendekatan untuk memperoleh data. Dalam penelitian ini menggunakan pendekatan naturalistik. Memakai pendekatan naturalistik karena didasari berbagai hal di antaranya : melalui pendekatan ini, peneliti berperan sebagai human instrumen, dan secara meneyeluruh peneliti dapat menyesuai kan diri dalam situasi yang wajar dengan natural setting berdasarkan keadaan lingkungan yang dimasuki, sehingga dengan itu data yang dibutuhkan bisa diperoleh seakurat mungkin, dan tetap memposisikan diri secara netral dalam memaparkan kondisi yang sebenarnya dan bisa menghindarai bias yang akan merugikan dan menjadikan data yang diperoleh tidak valid.

\section{Teknik Pengumpulan Data}

Sesuai dengan bentuk kajian yang diangkat dalam penelitian ini yaitu bersifat deskriptif kualitatif, maka diperlukan kiat untuk mengumpulkan informasi melalui teknik pengumpulan data. Teknik pengumpulan data yang digunakan dalam penulisan karya ini adalah :

a. Wawancara secara lisan dan jawabannyapun secara lisan pula untuk memperoleh data dari informan. Wawancara dalam penelitian ini dilakukan kepada para peserta diklat dan juga kepada panitia Diklat Teknis Substantif guru mata pelajaran Ushul Fikih MAK dengan jumlah informan 30 orang peserta dan 3 orang panitia. Hal ini dilakukan untuk memperoleh data mengenai keefektifan pembelajaran menggunakan pendekatan saintifik yang dipadu dengan model discovery learning.

b. Dokumentasi dan catatan lainnya yang relevan berupa nilai akhir dari peserta diklat dan nilai nasasumber /widyaiswara yang mengajar pada DTS guru mata pelajaran Ushul Fikih MAK. Dokumentasi digunakan untuk melengkapi data hasil observasi dan wawancara.

\section{Teknik Analisis Data}

Data yang telah terkumpul itu dianalisis secara deskriptif kualitatif di samping membandingkan antara satu informasi dengan informasi lainnya. Hal ini perlu agar diperoleh data yang valid dan terhindar dari sifat bias.

\section{Tempat dan Waktu Penelitian}

Lokus penelitian dilakukan di Balai Diklat Keagamaan (BDK) Padang mulai dari tanggal pelaksanaan diklat mata pelajaran Ushul Fikih MAK yang pelaksanaannya dimulai dari tanggal 27 Mei s.d. 01 Juni 2019. Sedangkan waktu penelitian dilaksana kan semenjak berlangsungnya diklat sampai tanggal 30 Juni 2019. 


\section{PEMBAHASAN}

\section{Pelaksanaan Diklat}

Berdasarkan hasil temuan melalui wawancara dan data yang terdokumentasi di Balai Diklat Keagamaan Padang, perpaduan antara pendekatan saintifik dengan penerapan model discovery learning dalam pembelajaran Diklat Teknis Substantif guru Mata Pelajaran Ushul Fikih MAK telah berjalan lancar dengan hasil akhir yang cukup membanggakan. Keberhasilan pelaksana an Diklat Teknis Substantif guru mata pelajaran Usul Fikih MAK ini tidak saja diukur dari nilai akhir yang diperoleh peserta Diklat, akan juga dapat dilihat dari aspek proses pembelajaran dan antusias peserta dalam mengikuti kegiatan.

Indikator yang menunjukkan bahwa proses pembelajaran diikuti secara serius terlihat dalam perolehan nilai sikap yang berada pada posisi rata-rata 88,4 , naik $10,5 \%$ dari nilai awal (80). Ini artinya, kegiatan pembelajaran dalaam Diklat dapat respon positif dan menunjukkan adanya kenaikan nilai sikap dalam mengikuti rangkaian kegiatan yang ditentukan dan disiplin waktu.

\section{Perencanaan/Program Diklat}

Diklat Teknis Substantif guru mata pelajaran Ushul Fikih MAK yang dilaksanakan di Balai Diklat Keagamaan Padang bertujuan untuk meningkatkan pemahaman peserta Diklat tentang materi Ushul Fikih yang meliputi Ruang Lingkup dan Proses Penukilan Hukum Ushul Fikih, Perbedaan Fikih dengan Ushul Fikih Sejarah Perkembangan Ilmu Ushul Fikih, dan Aliran Aliran Ushul Fikih untuk dapat melaksanakan tugas dan fungsi sebagai pengampu mata pelajaran Ushul Fikh MAK.

Sesuai dengan data yang diperoleh, pelaksanaan diklat guru mata pelajaran Ushul Fikh MAK telah memenuhi standar efektifitas sebuah diklat dari aspek perencanaan dan program diklat. Dengan kata lain, efektiitas aspek perencanaan dan program kediklatan sudah terpenuhi. Hal itu tidak diragukan lagi, karena kegiatan diklat sudah merupakan tugas pokok sebuah Balai Diklat dan kegiatan rutinitas setiap tahun.

\section{Nara Sumber/Widyaiswara}

Seperti yang dijelaskan sebelumnya bahwa Diklat Teknis Substantif guru mata pelajaran Ushul Fikih MAK untuk tahun anggran 2019 hanya satu angkatan. Mata diklat ini seperti halnya DTS lainnya terdiri atas kelompok dasa, kelompok inti, dan kelompok penunjang berdurasi 60 Jam Pembelajaran (JP) tatap muka. Untuk materi diklat kelompok inti melibatkan narasumber /widyaiswara berasal dari BDK Padang dan Universitas Islam Negeri (UIN) Imam Bonjol Padang.

Dalam melakukan kegiatan kediklatan tersebut, setiap narasumber/widyaiswara mendapat penilai an dari peserta Diklat. Penilaian tersebut sebagai tolak ukur pelaksanaan pembelajaran yang dilakukan widyaiswara / instruktur meliputi 14 item penilaian. Perolehan nilai dari peserta diklat dapat dilihat pada tabel berikut :

Tabel 2 :

Hasil Penilaian peseta terhadap Narasumber/Widyaiswara

\begin{tabular}{|c|c|c|c|}
\hline No & $\begin{array}{c}\text { Aspek yang } \\
\text { Dinilai }\end{array}$ & $\begin{array}{c}\text { Rerata } \\
\text { Nilai }\end{array}$ & $\begin{array}{c}\text { Keterang } \\
\text { an }\end{array}$ \\
\hline 1 & Pengetahuan dan & 94 & \\
\hline
\end{tabular}




\begin{tabular}{|c|l|c|c|}
\hline & $\begin{array}{l}\text { keterampilan } \\
\text { mengajar }\end{array}$ & & \\
\hline 2 & $\begin{array}{l}\text { Penguasaan } \\
\text { materi }\end{array}$ & 95 & \\
\hline 3 & $\begin{array}{l}\text { Sistematika } \\
\text { penyajian }\end{array}$ & 92,6 & \\
\hline 4 & $\begin{array}{l}\text { Kemampuan } \\
\text { menyajikan }\end{array}$ & 92 & \\
\hline 5 & $\begin{array}{l}\text { Penggunaan } \\
\text { metode dan alat } \\
\text { bantu } \\
\text { pembelajaran }\end{array}$ & 91,5 & \\
\hline 6 & $\begin{array}{l}\text { Ketercapaian } \\
\text { tujuan } \\
\text { pembelajaran }\end{array}$ & 92,1 & \\
\hline 7 & $\begin{array}{l}\text { Etika dalam } \\
\text { pembelajaran }\end{array}$ & 96 & \\
\hline 8 & $\begin{array}{l}\text { Sikap terhadap } \\
\text { peserta diklat }\end{array}$ & 94,06 & \\
\hline 9 & $\begin{array}{l}\text { Cara menjawab } \\
\text { pertanyaan } \\
\text { peserta }\end{array}$ & 92,4 & \\
\hline 10 & $\begin{array}{l}\text { Penggunaan } \\
\text { bahasa }\end{array}$ & 94 & \\
\hline 11 & $\begin{array}{l}\text { Pemberian } \\
\text { motivasi }\end{array}$ & 95 & \\
\hline 12 & Disiplin waktu & 92,80 & \\
\hline 13 & $\begin{array}{l}\text { Kerapian } \\
\text { berpakaian }\end{array}$ & $\begin{array}{l}\text { Kerjasama } \\
\text { apabila tim) }\end{array}$ & - \\
\hline Sum & & \\
\hline 14 . & \\
\hline
\end{tabular}

Sumber; Laporan Penyelenggaraan Diklat

Tabel di atas mengekspresikan pandangan dan penilaian peserta terhadap narasumber / widyaiswara. Dari tabel itu dapat dipahami bahwa tanggapan terhadap para pengajar secara general sangat positif yang ditandai dengan pemberian nilai rata-rata jauh di atas standar. Nilai rata-rata yang diperoleh narasumber/widyaiswara yang mengajar mata diklat inti pada diklat tersebut adalah 90,95. Ini juga sebagai salah satu indikator keberhasilan pembelajaran dalam Diklat.

Berdasarkan hasil penilaian peserta terhadap narasumber/widyaiswara dalam berbagai aspek menunjukkan bahwa, pembelajaran yang dilaksanakan telah memenuhi kriteria pembelajaran efektif.

\section{Aspek Tujuan/Hasil}

Berdasarkan tabel di atas dipahami bahwa, nilai akhir yang merupakan gabungan dari kehadiran, kedisiplinan, keaktifan, tugas, dan nilai ujian, peserta diklat yang jumlahnya 30 orang memperoleh nilai di atas rata-rata. Nilai tertinggi 86,02 dan nilai akhir terendah 8,00 .

Perolehan nilai akhir menunjuk kan bahwa, seluruh peseta diklat berhasil dalam mengikuti kegiatan kediklatan dan memperoleh nilai akhir di atas nilai minimal untuk lulus $(7,6)$ dan memperoleh nilai akhir dengan sebutan amat kompeten dan kompeten. Dengan arti kata, $100 \%$ peseta DTS guru mata pelajaran Ushul Fikih MAK dengan pola pembelajaran memadukan pendekatan saintifik dengan model discovery learning seluruh peserta memperoleh sebutan kompeten.

Mengacu pada hasil observasi dan wawacancara terhadap beberapa widyaiswara yang terlibat langsung dalam proses pembelajaran dan peserta diklat guru mata pelajaran Ushul Fikih MAK, dapat dideskripsikan bahwa pelaksanaan pembelajaran berjalan dengan baik dan efektif, peserta diklat cukup antusias dan aktif dalam pembelajaran. Seluruh materi diklat diikuti dengan cukup serius karena menganggap seluruh materi Diklat dibutuhkan oleh peserta. Hal ini dapat dilihat pada tabel berikut.

Tabel 3 :

Pandangan peserta terhadap keurgenan materi (Kelompok Inti)

\begin{tabular}{|c|c|c|c|c|}
\hline No & Materi Diklat & $\begin{array}{c}\text { Alter- } \\
\text { Natif }\end{array}$ & F & $\%$ \\
\hline
\end{tabular}




\begin{tabular}{|c|c|c|c|c|}
\hline 1 & $\begin{array}{l}\text { Analisis SKL, } \\
\text { KI, KD dan } \\
\text { Indikator } \\
\text { Fikih-Ushul } \\
\text { Fikh MAK (6 } \\
\text { JP) }\end{array}$ & $\begin{array}{l}\text { a. } \text { sangat } \\
\text { penting } \\
\text { b. penting } \\
\text { c. kurang } \\
\text { penting }\end{array}$ & $\begin{array}{c}20 \\
10 \\
-\end{array}$ & $\begin{array}{c}66,6 \\
33,7 \\
-\end{array}$ \\
\hline \multicolumn{3}{|c|}{ Jumlah } & 30 & 100 \\
\hline No & Materi Diklat & $\begin{array}{l}\text { Alter- } \\
\text { Natif }\end{array}$ & $\mathbf{F}$ & $\%$ \\
\hline 2 & $\begin{array}{l}\text { Ruang } \\
\text { Lingkup dan } \\
\text { Proses } \\
\text { Penukilan } \\
\text { Hukum Ushul } \\
\text { Fikh ( 7 JP) } \\
\end{array}$ & $\begin{array}{l}\text { a. sangat } \\
\text { penting } \\
\text { b. penting } \\
\text { c. kurang } \\
\text { penting }\end{array}$ & $\begin{array}{l}28 \\
2 \\
-\end{array}$ & $\begin{array}{c}93,3 \\
6,7 \\
-\end{array}$ \\
\hline \multicolumn{3}{|c|}{ Jumlah } & 30 & 100 \\
\hline No & Materi Diklat & $\begin{array}{l}\text { Alter- } \\
\text { Natif }\end{array}$ & $\mathbf{F}$ & $\%$ \\
\hline 3 & $\begin{array}{l}\text { Perbedaan } \\
\text { Fikih dengan } \\
\text { Ushul Fikih } \\
\text { (7 JP) }\end{array}$ & $\begin{array}{l}\text { a. sangat } \\
\text { penting } \\
\text { b. penting } \\
\text { c. kurang } \\
\text { penting }\end{array}$ & $\begin{array}{l}24 \\
6 \\
-\end{array}$ & $\begin{array}{c}80 \\
20 \\
-\end{array}$ \\
\hline \multicolumn{3}{|c|}{ Jumlah } & 30 & 100 \\
\hline No & Materi Diklat & $\begin{array}{l}\text { Alter- } \\
\text { Natif }\end{array}$ & $\mathbf{F}$ & $\%$ \\
\hline 4 & $\begin{array}{l}\text { Sejarah } \\
\text { Perkembangan } \\
\text { Ilmu Ushul } \\
\text { Fikih (7 JP) }\end{array}$ & \begin{tabular}{|l} 
a. sangat \\
penting \\
b. penting \\
c. kurang \\
penting \\
\end{tabular} & $\begin{array}{l}25 \\
5 \\
-\end{array}$ & $\begin{array}{c}83,3 \\
16,7 \\
-\end{array}$ \\
\hline \multicolumn{3}{|c|}{ Jumlah } & 30 & 100 \\
\hline No & Materi Diklat & $\begin{array}{l}\text { Alter- } \\
\text { Natif }\end{array}$ & $\mathbf{F}$ & $\%$ \\
\hline 5 & $\begin{array}{lr}\text { Aliran } & \text { Aliran } \\
\text { Ushul } & \text { Fikih } \\
\text { (8 JP) } & \end{array}$ & \begin{tabular}{|l} 
a. sangat \\
penting \\
b. penting \\
c. kurang \\
penting \\
\end{tabular} & $\begin{array}{l}30 \\
- \\
-\end{array}$ & $\begin{array}{l}100 \\
- \\
-\end{array}$ \\
\hline \multicolumn{3}{|c|}{ Jumlah } & 30 & 100 \\
\hline No & Materi Diklat & $\begin{array}{c}\text { Alter- } \\
\text { natif }\end{array}$ & $\mathbf{F}$ & $\%$ \\
\hline 6 & $\begin{array}{l}\text { Praktik } \\
\text { Pembelajar an } \\
\text { Fikih-Ushul } \\
\text { Fikih (8 JP) }\end{array}$ & \begin{tabular}{|l} 
a. sangat \\
penting \\
b. penting \\
c. kurang \\
penting \\
\end{tabular} & 30 & $\begin{array}{l}100 \\
- \\
-\end{array}$ \\
\hline \multicolumn{3}{|c|}{ Jumlah } & 30 & 100 \\
\hline
\end{tabular}

Tabel di atas mendeskripsikan bahwa, mata diklat kelompok inti dalam diklat guru mata pelajaran Ushul Fikih MAK cukup diminati dan dinggap sangat penting oleh peserta diklat.
Seluruh mata diklat inti yang jumlahnya 6 (enam) mata diklat, dinggap sangat penting oleh peserta diklat yaitu rata-rata $87,2 \%$ audien berpandangan bahwa mata Diklat kelompok inti sangat krusial. Sedangkan yang mengatakan mata diklat kelompok inti itu penting rata-rata 12,8 $\%$. Dengan demikian dapat dikatakan bahwa, seluruh peserta diklat memandang keseluruhan mata diklat inti adalah sangat menentukan dan bersifat krusial.

\section{Kendala dalam Pembelajaran Menggunakan Model Discovery Learning}

Sekalipun diakui bahwa, perpaduan pendekatan saintifik dengan model discovery learning sangat ideal dalam menggali materi Ushul Fikih MAK dan menjadikan pembelajaran menyenang kan, namun bukan berarti, penerapan model ini lepas dari kelemahan dan kendala. Setiap penerapan model dipastikan ada kelebihan dan kelemahan nya begitu pula halnya dengan model discovery learning.

Ada sejumlah problema yang dialami dalam perpadauan antara saintifik dengan penerapan model pembelajaran discovery learning di antaranya : (a) pemahaman peserta diklat tentang saintifik sebagai sebuah pendekatan masih rendah begitu juga halnya dalam penerapan model discovery leaarning dalam pembelajar an; (b) adanya persepsi peseta diklat tentang ketidak-sesuaian materi dengan penggunaan model discovery learning, (c) adanya budaya belajar peserta diklat yang masih pasif, yaitu menunggu instruktur/widyaiswara menyampaikan materi terlebih dahulu; dan (d) 
membudayanya cara mengajar peserta diklat yang klasik yaitu kecenderungan menerangkan materi secara tuntas.

Penerapan pendekatan santifik yang dipadu dengan model pembelajaran discovery learning dalam kegiatan belajar mengajar tidak terlepas dari berbagai kendala dan hambatan yang ditemui, tidak saja dari aspek peseta diklat namun juga dari sudut widyaiswara. Salah satu kendala penerapan model pembelajaran discovery learning pada Diklat Mata Pelajaran Ushul Fikih MAK adalah sulitnya merubah mindset para peseta diklat untuk menerima dan menerapkan pola pembelajaran yang berbasis / berpusat pada peserta diklat dan melibatkan mereka secara fisik dalam pembelajaran.

Saintifik sebagai sebuah pendekatan ilmiah dan pola pembelajaran discovery learning merupakan salah satu wujud dari pendekatan saintifik yang diterapkan dalam pembelajaran menurut kurikulum 2013 diakui agak sulit menerapkannya dalam kegiatan pembelajaran diklat karena selama ini pembelajaran hanya menerapkan modelmodel pembelajaran menurut kurikulum 2006 (KTSP). Namun disadari bahwa model discovery learning dapat mendorong peserta diklat untuk aktif melakukan kegiatan searching (mencari) materi dan mengontruksinya melalui pengamatan, dan diakhiri dengan mengkomunikasikan sebenaranya merupakan barang baru bagi peserta peserta diklat.

Bersadarkan hal tersebut di atas, maka kegiatan pembelajaran dengan penerapan pola ini menuntut instruktur /widyaiswara lebih profesional lagi untuk membimbing peserta peserta diklat secara teknis bagaimana mengembangkan tugas yang bisa memotivasi/mendorong peserta peserta diklat melakukan pengamatan yang sungguh-sungguh, tekun, jujur, obyektif, dan tajam dalam mengamati, memberikan umpan balik dan mendorong peserta peserta diklat untuk terstimuli (al-hass) untuk dapat mengembangkan ide kreatifnya secara optimal.

\section{KESIMPULAN}

Perpaduan pendekatan saintifik dengan model discovery learning pada intinya adalah model pembelajaran dengan bentuk menemukan yaitu sebuah pola pembelajaran dengan cara memfasilitasi para peserta didik/peserta diklat menemukan dan memperoleh materi ajar. Penerapan santifik dan model discovery ini pembelajaran dirancang sedemikian rupa agar peserta didik/peserta diklat memperoleh pengetahuan secara runtut mulai dari fakta, konsep, prinsip, dan prosedur melalui proses mentalnya sendiri sesuai dengan prinsip filsafat pengetahuan yang dimulai dari pengamatan, bertanya, penalaran, asosiasi dan berakhir dengan mengomunikasikan/ mempresentasikan.

Model discovery learning pada intinya merupakan sebuah prosedur dalam pembelajaran yang mementing kan pengajaran dilakukan oleh instruktur/widyaiswara secara perseorangan, mementingkan pengajar an perseorangan, memanipulasi objek sebelum sampai pada generalisasi (alnatijah). 
Penerapan pendekatan saintifik dengan model pembelajaran discovery learning dalam pembelajaran Ushul Fikih ternyata dapat merubah kondisi pembelajaran yang pasif menjadi aktif dan kreatif. Mengubah pembelajaran dengan pola teacher oriented menjadi student oriented, dan juga mengubah modus ekspositor peserta didik/peserta diklat yang selalu hanya sebatas menerima informsi secara utuh dari narasumber/widyasiawara menjadi modus discovery yaitu mencari dan menemukan informasi.

\section{Saran/Rekomendasi}

Saintifik merupakan pendekatan untuk memperoleh pengetahuan, sedangkan discovery learning adalah model pembelajaran, merupakan pola baru dalam proses belajar mengajar lahir setelah munculnya kurikulum 2013. Inti dari kedua terma itu adalah menjadi kan pembelajaran tidak lagi semata-mata terfokus kepada instruktur/wadyaiswara dalam pembelajaran. Oleh karena itu, agar pembelajaran menjadi aktif dan kreatif, hendaknya pendekatan saintifik itu dipadukan dengan model ini agar pembelajaran lebih bermakna.

Perpaduan saintifik dengan model pembelajaran discovery learning dalam pembelajaran terutama dalam DTS guru mata pelajaran Ushul Fikih sangat tepat, sebab para peserta diklat terlibat langsung dalam pembelajaaran dan mereka didorong untuk menemukan, dan kemudian merumuskan. Untuk terwujud nya pembelajaran yang adaptif dan penuh arti apalagi mata pelajaran Ushul Fikih yang merupakan "epistemologi" pengetahuan dalam hukum Islam, maka widyaiswara hendaknya dapat memadu- kan antara santifik dengan pola pembelajaran discovery learning agar pembelajaran semakin menampakkan hasil dalam menggali ajaran Islam.

\section{REFERENSI}

Abdul, Majid, 2014. Pembelajaran Tematik Terpadu. Bandung: Remaja Rosdakarya.

Amar, Raichul, 2007, Metodologi Penelitian: Sebuah Pengantar, Padang, IAIN Press

Anam, Khairul, 2006, Pembelajaran Berbasis Inkuiri: Metode dan Aplikasi, Yokyakarta: Pustaka Pelajar

E. Mulyasa, 2014, Guru dalam Implementasi Kurikulum 2013, Bandung: Remaja Rosdakarya

Hosnan, M. 2014. Pendekatan Saintifik dan Kontekstual dalam Pembelajaran Abad 21, Bogor: Ghalia Indonesia

Nata, Abuddin ,2009, Perspektif Islam Tentang Strategi Pembelajaran, Jakarta: Kencana Prenada Media

Suparman, Atwi, 1997, Model-model Pembelajaran Interaktif, Jakarta: Lembaga Administrasi Negara (LAN)

Sadia, I Wayan Sadia, 2014, Model-model Pembelajaran Sains Konstruktivistik, Yokyakarta Graha Ilmu

Supritiningrum, Jamil, 2013, Strategi Pembelajaran: Teori dan Aplikasi, Jokjakarta, Ar-Ruzz Media

Sugiyono, 2015, Metode Penelitian Pendidikan (Pendekatan Kuantitati dan Kualitatif, Bandung, Alfabeta

Tim MKDP, 2011, Kurikulum \& Pembelajaran, Jakarta: Raja grapindo Persada

Purwastuti, (2016), Teknik Perkonsultasian Diklat, Jakarta: Lembaga Admnistrasi Negara (LAN) Republik Indonesia. 